Transnational Cultures of Expertise 


\section{Colloquia Augustana}

Edited

on behalf of the Institute of European Cultural History of the University of Augsburg

by Ulrich Niggemann, Bernd Oberdorfer, Lothar Schilling, Silvia Serena Tschopp, and Gregor Weber

Editorial staff

Jessica Schreyer

\section{Volume 36}




\section{Transnational Cultures of Expertise}

Circulating State-Related Knowledge in the $18^{\text {th }}$ and $19^{\text {th }}$ Centuries

Edited by

Lothar Schilling and Jakob Vogel 
ISBN: 978-3-11-055180-8

e-ISBN (PDF) 978-3-11-055373-4

e-ISBN (EPUB) 978-3-11-055184-6

ISSN 0946-9044

Library of Congress Control Number 2019946030

Bibliographic information published by the Deutsche Nationalbibliothek

The Deutsche Nationalbibliothek lists this publication in the Deutsche Nationalbibliografie;

detailed bibliographic data are available from the Internet at http://dnb.dnb.de.

(C) 2019 Walter de Gruyter GmbH, Berlin/Boston

Typesetting: Integra Software Services Pvt. Ltd

Printing and binding: CPI books $\mathrm{GmbH}$, Leck

Cover image: August Ludwig von Burgsdorf[f]: Versuch einer vollständigen Geschichte vorzüglicher Holzarten in systematischen Abhandlungen zur Erweiterung der Naturkunde und

Forsthaushaltungs-Wissenschaft, Berlin 1783-1800, $2^{\text {nd }}$ volume (front page).

www.degruyter.com 